\title{
Review on Plant diversity Status and Conservation Practices in Nepal
}

Joshi (Shrestha) Sudha

\begin{abstract}
Plant diversity plays the crucial role in maintaining the ecosystem and sustaining the life in the globe. Nepal lying in central Himalaya and at the crossroad of two phytogeographicregionsis bestowed with rich biodiversity. Though the country occupies about $0.1 \%$ of global land area but comprises 3.2\% of world's known flora. Biodiversity is eroding because of many factors such as habitat loss, deforestation, infrastructure development, over exploitation for human use, invasion by alien species, global climate change and natural calamities, thus threatening the existence in globe.Nepal has adopted both in-situ and ex-situ conservation practices to conserve the biodiversity and maintain the ecosystem in nature. A network of 20 protected areas is established and national forests under different categories are under protectionto conserve the biodiversity in their natural habitats.Scientific forest management was initiated to enhance the forest productivity and conserve biodiversity. Botanical gardens in different localities are established for the conservation of rare, endangered, threatened and endemic plant species. Moreover, Government of Nepal has enlisted some plant species in Government protection list and CITES appendices to prevent them from degradation. Thirty three plant species with medicinal values are prioritized for research and economic development of the nation.Nepal's approach in conservation of plant diversity is commendable and is at the forefront in in-situ conservation practice. However, a considerable number of plants speciesthat are rare, threatened, endemic are also found outside the protected areasand need to be conserved.
\end{abstract}

Key words: Plant diversity, Ex-situ; In-situ, Protected areas, Nepal.

\section{Itroduction}

Biological diversity or biodiversity refers to the range of variations or differences among the living organisms of the world, and thus includes all the life forms from unicellular microscopic organisms to multicellular plants and animal with complex bodies. The term "Biological diversity" was first coined by Dasman in 1968, who also advocated the urgent need for conservation of biodiversity. The Convention on Biological Diversity(CBD, 1992),in its article 2 has defined the biological diversity "as the variability among living organisms from all sources including, inter alia, terrestrial, marine and other aquatic ecosystems and the ecological complexes of which they are part: this includes diversity within species, between species and of ecosystems"(CBD 1992). 
Biodiversity plays the crucial role in supporting the life in earth and maintaining the global ecosystem. It is important in a number of ways: 1 . Species are used as food, fodder, fuel, medicines etc. 2. Products from species are sold in national and international markets. 3. Biodiversity balances the ecosystem that provides a number of ecological services including the nutrient cycling and plant pollination. Species have social and cultural value, educational value, aesthetic value and economic value. The natural resources are the primary source of useful commodities and the biodiversity resources especially the forest resource is the main source of basic needs such as food, fodder, fiber, medicine etc. of human beings. The rural people still depend upon the forest products for their livelihood and primary health care. About $60 \%$ of population of the world and $80 \%$ of population of Nepal rely on traditional medicinal herbs present around them to cure different ailments (Shrestha and Dillion, 2003).Nepal is bestowed with rich biodiversity both in flora and fauna. The elevationgradients in Nepal range from $60 \mathrm{~m}$ above sea level in the Tarai to $8848 \mathrm{~m}$ of Mount Everest, the highest peak of the world (MoFSC, 2002). Different bioclimatic zones, rich edaphic factors combined with varied topographic conditions have created the area as the huge repository of both flora and fauna. Moreover, Nepal's position in the central region of Himalayan range and being at the crossroads of the Indo-Malayan and Palearctic phytogeographic regionsmade the country a mixing place of species originating in both the regions.It is reported that the most diverse elevation zone in Himalayan range in terms of species richness probably lies between 1,500 and 2,500 m (Barthlott et al., 2005). The Global Strategy for Plant Conservation (GSPC) was adopted by CBD in 2002 for raising the awareness of the threats faced by plants worldwide and providing policy and action needed to halt the loss of plant diversity. The GSPC: 2011 -2010 has visioned the plant diversity as "Without plants, there is no life. The functioning of the planet and our survival depends on plants. "The strategy seeks to halt the continuing loss of plant diversity." (http://www.cbd.int/gspc/). However, because of many challenging factors such as habitat loss, deforestation, overexploitation, forest fire, pollution, climate change etc., many plant species are and threatened and in danger of extinction. Forest is the one of the most important natural resourcesof Nepal and habitat of plant diversity. In contest to Nepal, forest coverage and biodiversity did not decline for centuries as the people apply their wisdom to save or promote natural resourcesfor their own survival (Basnet, 1992).However, currently the deforestation and biodiversity loss is the issue in every corner of the global and biodiversity in globe is eroding in alarming rate. In developing countries, basically deforestation is due to population growth and agricultural expansion, aggravated over the longterm by wood harvesting for fuel and export (Allens and Barnes, 1985). However, in Nepal besides the population pressure, subsistence agriculture expansion encroaching forestlands, illegal timber harvesting and forest fire, livestock grazing, daily fuelwood 
consumption, development activities and conflicting policies are the main causes of deforestation (Chaudhary et al., 2015). Because of those different driving forces, the forest coverage and the biodiversity in the country had decreased drastically few decades ago. Hence to mitigate the forest coverage decline and conserve the biodiversity, Nepal has formulated a number of policies and legislatives and to ensure the basic needs of local communities and sustainable forest management. Nepal also signed in United Nations Convention on Biological Diversity (UNCBD) in 1992 and working with the spirit of the convention. A number of institutions have been engaged to conserve, manage and use the biological diversity in sustainable way. Ministry of Forests and Environment and its divisions and departments are fully engaged in biodiversity conservation. Department of National Parks and Wildlife Conservation are engaged in protected areas (PAs) management and biodiversity conservation. Department of Soil Conservation and Watershed Management look after the soil and water related issues which are the basis for biodiversity existence. Agrobiodiversity related issues are looked from Ministry of Land Reforms, Agriculture and Cooperative.

Establishment and management of Protected Areas is the best way to conserve and safeguard the biodiversity. However a number of taxonomically important, rare, endangered biodiversity also lie outside the PAs. Out of the total area of forest of Nepal, $82.68 \%$ lies outside the PAs and 17.32\% inside the PAs (DFRS 2015). Thus a considerable number of biodiversity which are rare, threatened, endemic and vulnerable also exist outside the PAs. Human pressure on the resource utilization outside PAs creates the loss of such biodiversity. Biodiversity specially the forest diversity outside the PAs are threatened mainly by deforestation and forest degradation caused by various factors such as through land use conversion for agriculture, illegal settlements, infrastructures (including roads and electric transmission lines) and actions relating to the use of resources including overgrazing, unsustainable exploitation of forest products, habitat fragmentation and uncontrolled forest fires (MoFSC, 2014a).

In order to increase understanding and awareness of biodiversity issues, UN has proclaimed 22 May as "The International Day for Biological Diversity (IDB)". CBD decides a theme for the day every year and different institutions in Nepal are also celebrating the day to generate the awareness on the needs of conservation of biodiversity.

In this paper, a review was done in the plant diversity status and conservation practices in Nepal to disseminate the latest data so far possible.

\section{Data Source}

This review paper was based on the information and data compiled from the published literatures and grey literatures. 


\section{Status of Plant Diversity In Nepal}

Nepal ranked in $49^{\text {th }}$ position in world biodiversity (Groombridge and Jenkins, 2000).Nepal covers about $0.1 \%$ of global land area, but harbours $3.2 \%$ and $1.1 \%$ of world's flora and fauna respectively (Kharal and Dhungana, 2018).However in terms of floral diversity, it comprises 3.2\% of world's known flora with 2.5\% (1001 species) of algae, 5.1\% (534 species) of pteridophytes, 5.1\% (26 species) of gymnosperms and 3.2\%(6973 species) of angiosperms (MoFSC, 2014b). Altogether 2,467 species of fungi, 792 species of lichens and 1,213species of bryophytes are reportedfrom Nepal (MoFE, 2018), Nepal ranks $10^{\text {th }}$ in terms of richest flowering plant diversity in Asia and $31^{\text {st }}$ in the world (Shrestha, 2016).The rich biodiversity plays the crucial role in livelihood of the people and economic development of nation.

With regard to agriculture biodiversity, 11,389accessions of 52 crops from 62 districts are deposited in the National Gene Bank and of 790 plant species including 577 cultivated plants are useful for food (MoFE, 2018).

\subsection{Threats to Plant Diversity}

Presently, the biodiversity of world is facing the treats from many factors and threats on the ecosystems and species are no exceptions in Nepal as well. Nepal's Sixth National Report to the CBD has identified30 threats prevailed on different ecosystems of the nation in different provinces (MoFE, 2018).Threat rankings were categorized into four categories viz. low, moderate, high and very high. Among the different ecosystems, forest ecosystem and mountain biodiversity were highly threatened.

The main threats posed by the plant diversity in the country are habitat loss, deforestation and degradation, infrastructure development, over exploitation for human use, invasion by alien species, global climate change, natural calamities, over exploitation of NTFPs and MAPs, forest fire etc.However, among those, human intervention in the natural ecosystem is one of the major threats for biodiversityloss in Nepal especially in the urban areas. Intervention in the ecosystem by human beings disturbs the biodiversity and becomes threatened for their existence. Mostly the species with narrow geographical range, with one or only a few populations, small sized population, with declining population size, and overexploited species become more vulnerable to extinction by such anthropogenic activities. It is reported that the current extinction ratesare believed to be 1,000 times higher than natural background rates of extinction and future rates are likely to be 10,000 timeshigher (De Vos, 2014). If species has lost once, that is forever and irreplaceable.Within the assessed species, more than 32,000 species which are threatened with extinction (www.iucnredlist.org). Hence, conservation and sustainable use of biodiversity is of utmost need to maintain the life in earth for present and future generation. The threat assessments of biodiversity in different provinces are given in Table 1. 
Patan Pragya (Volume: 6, Number: 1 2020)

Table . 1. Threat assessment of biodiversity in different Provinces

\begin{tabular}{|c|c|c|c|c|c|c|c|c|}
\hline \multirow{2}{*}{$\begin{array}{l}\text { Ecosys } \\
\text { tems }\end{array}$} & \multirow[t]{2}{*}{ Threats } & \multicolumn{7}{|c|}{ Provinces } \\
\hline & & 1 & 2 & 3 (Bag.) & 4(Gand.) & 5 & 6 (Kar.) & 7(Spa.) \\
\hline \multirow[t]{5}{*}{ Forests } & $\begin{array}{l}\text { Habitat loss } \\
\text { and } \\
\text { deforestation }\end{array}$ & Moderate & High & High & Moderate & Moderate & $\begin{array}{l}\text { Moderat } \\
\mathrm{e}\end{array}$ & High \\
\hline & $\begin{array}{l}\text { Illegal hunting } \\
\text { and trade }\end{array}$ & Moderate & $\begin{array}{l}\text { Moderat } \\
\text { e }\end{array}$ & Moderate & Moderate & Moderate & $\begin{array}{l}\text { Moderat } \\
\mathrm{e}\end{array}$ & $\begin{array}{l}\text { Moderat } \\
\text { e }\end{array}$ \\
\hline & $\begin{array}{l}\text { Human } \\
\text { wildlife } \\
\text { conflict }\end{array}$ & Moderate & $\begin{array}{l}\text { Moderat } \\
\text { e }\end{array}$ & High & High & High & $\begin{array}{l}\text { Moderat } \\
\text { e }\end{array}$ & High \\
\hline & $\begin{array}{l}\text { Invasion by } \\
\text { IAPs }\end{array}$ & Moderate & $\begin{array}{l}\text { Moderat } \\
\mathrm{e}\end{array}$ & High & Moderate & Moderate & High & $\begin{array}{l}\text { Moderat } \\
\mathrm{e}\end{array}$ \\
\hline & Forest Fire & Moderate & High & High & High & High & High & High \\
\hline \multirow{4}{*}{$\begin{array}{l}\text { Protect } \\
\text { ed } \\
\text { Areas }\end{array}$} & Poaching & Moderate & $\begin{array}{l}\text { Moderat } \\
\mathrm{e}\end{array}$ & Moderate & Moderate & Moderate & High & $\begin{array}{l}\text { Moderat } \\
\text { e }\end{array}$ \\
\hline & Grazing & High & High & Moderate & Moderate & High & $\begin{array}{l}\text { Very } \\
\text { High }\end{array}$ & $\begin{array}{l}\text { Very } \\
\text { High } \\
\end{array}$ \\
\hline & $\begin{array}{l}\text { Illegal Timber } \\
\text { harvesting }\end{array}$ & Low & $\begin{array}{l}\text { Moderat } \\
\mathrm{e}\end{array}$ & Moderate & Moderate & Moderate & High & $\begin{array}{l}\text { Moderat } \\
\mathrm{e}\end{array}$ \\
\hline & $\begin{array}{l}\text { Uncontrolled } \\
\text { tourism }\end{array}$ & Low & Low & Moderate & Moderate & Moderate & High & Low \\
\hline \multirow[t]{2}{*}{$\begin{array}{l}\text { Rangel } \\
\text { ands }\end{array}$} & Overgrazing & Moderate & High & Moderate & Moderate & $\begin{array}{l}\text { Very } \\
\text { High }\end{array}$ & High & High \\
\hline & $\begin{array}{l}\text { Invasion by } \\
\text { IAPs }\end{array}$ & Moderate & $\begin{array}{l}\text { Moderat } \\
\mathrm{e}\end{array}$ & High & Moderate & High & High & High \\
\hline \multirow[t]{5}{*}{$\begin{array}{l}\text { Wetlan } \\
\text { ds }\end{array}$} & $\begin{array}{l}\text { Human } \\
\text { encroachment }\end{array}$ & Moderate & High & Moderate & High & Moderate & High & High \\
\hline & Over-fishing & High & High & High & Moderate & Moderate & High & High \\
\hline & $\begin{array}{lr}\text { Wide } & \text { spread } \\
\text { mining } & \text { of } \\
\text { gravels } & \\
\end{array}$ & High & High & High & High & Moderate & High & High \\
\hline & $\begin{array}{l}\text { Illegal hunting } \\
\text { and trapping } \\
\text { of birds \& } \\
\text { other wild } \\
\text { animals }\end{array}$ & Moderate & $\begin{array}{l}\text { Moderat } \\
\text { e }\end{array}$ & Moderate & Moderate & Moderate & $\begin{array}{l}\text { Moderat } \\
\text { e }\end{array}$ & High \\
\hline & $\begin{array}{l}\text { Invasion by } \\
\text { IAPs }\end{array}$ & Moderate & $\begin{array}{l}\text { Moderat } \\
\mathrm{e}\end{array}$ & High & Moderate & Moderate & $\begin{array}{l}\text { Moderat } \\
\mathrm{e}\end{array}$ & $\begin{array}{l}\text { Moderat } \\
\mathrm{e}\end{array}$ \\
\hline $\begin{array}{l}\text { Agricul } \\
\text { ture }\end{array}$ & $\begin{array}{l}\text { Loss of } \\
\text { agrobiodiversi }\end{array}$ & High & High & High & High & High & High & High \\
\hline
\end{tabular}


Patan Pragya (Volume: 6, Number: 1 2020)

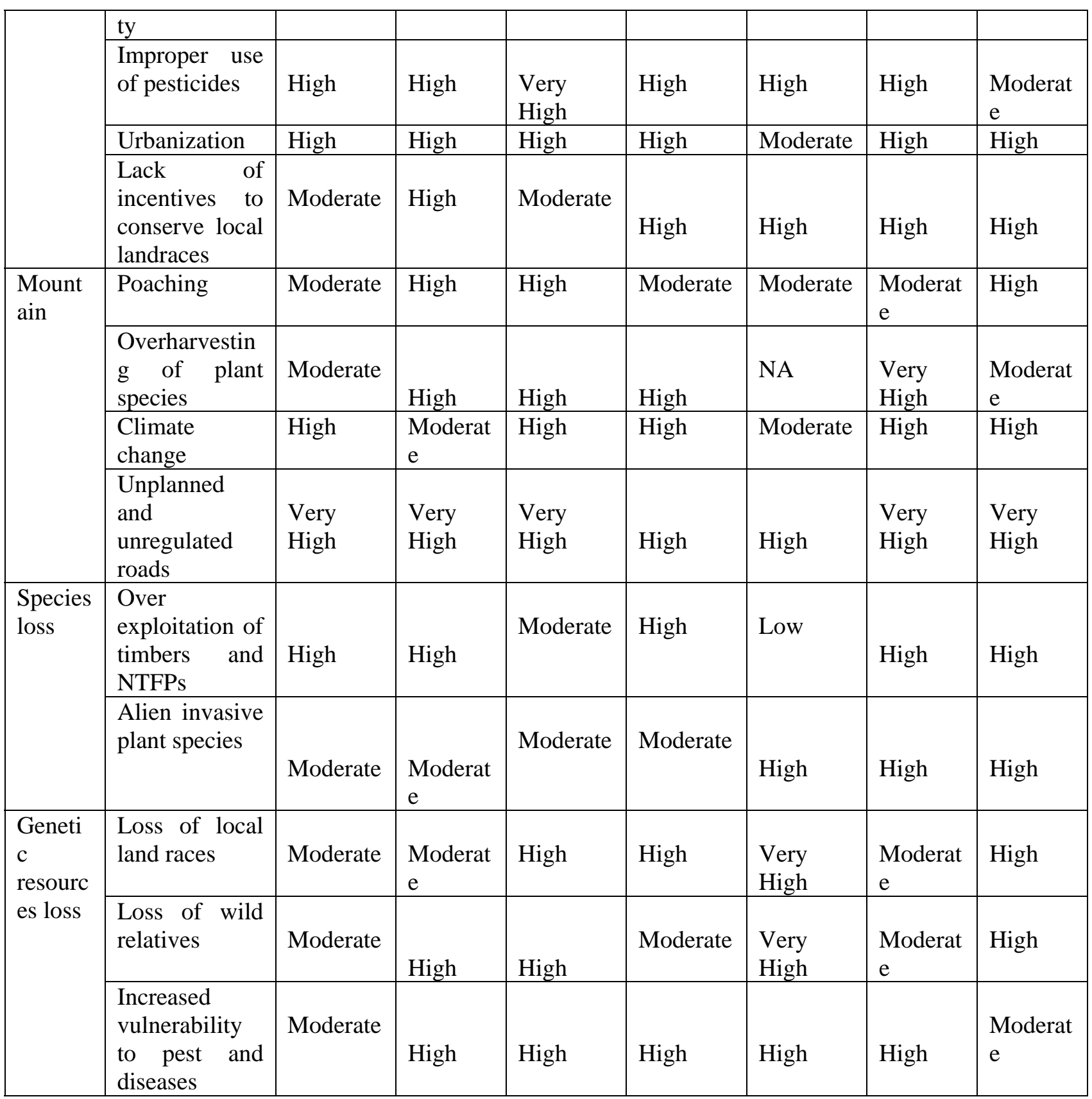

Source: MoFE 2018

Note: IAPs = Invasive alien plants; Bag = Bagmati; Gan = Gandaki; Kar = Karnali; Spa = Sudurpaschim

\section{Conservation Practices in Nepal}

As Nepal being a signatory to theConvention on Biological Diversity (CBD), Nepal is continuously working with the spirit of the convention and obliged to fulfill the objectives 
of the CBD including the conservation of biological diversity, its sustainable use and fair and equitable sharing of benefits from the utilization of genetic resources. To achieve these objectives of CBD, the contracting parties are neededto develop national strategies for the conservation of biodiversity. Both in-situ as well as ex-situ conservation methods are practiced in Nepal for the conservation and management of biodiversity.

\subsection{In-situ Conservation}

In-situconservation is the on-site conservation or conservation of biodiversity in their natural habitat. According to Glowkaet al. (1994), it also includes the conservation of domesticated or cultivated plant species in the surroundings where they have developed their distinctiveness. Article 8 of CBD (1992) promoted the contracting parties to establish a system of protected areasor areas where special measures need to be taken to conserve biological diversity.

\section{Protected Areas (PAs)}

With the goal of conservationof biodiversity and ecosystem, networks of 20 protected areas (PAs) are established in Nepal. Those PAs include 12 National parks, sixconservation areas, onewildlife reserve, one hunting reserve and 13 buffer zones(DNPWC, 2075 BS).CBD held at Nagoya city of Aichi Prefecture in 2010 has envisioned in expanding the protected area coverage by $17 \%$ on the terrestrial environment (Aichi Biodiversity target 11) by 2020 (CBD, 2010). However, Nepal is at the forefront in establishing the PAswith $23.39 \%$ or $34,419.75$ sq. $\mathrm{km}$ of the land area under protection (DNPWC, $2075 \mathrm{BS}$ ). The PAs established at different geographic regions is the major approach in biodiversity conservation in Nepal (Table. 2. Fig. 1).

Table 2.Protected areas of Nepal.

\begin{tabular}{|l|l|l|l|l|l|}
\hline SN & $\begin{array}{l}\text { Name of Protected } \\
\text { Area }\end{array}$ & Estd. (AD) & $\begin{array}{l}\text { Area Covered } \\
\left(\mathrm{Km}^{2}\right)\end{array}$ & $\begin{array}{l}\text { Buffer Zone } \\
\left(\mathrm{Km}^{2}\right)\end{array}$ & $\begin{array}{l}\text { Geographic } \\
\text { region }\end{array}$ \\
\hline 1. & Chitwan NP & 1973 & 952.63 & 729.37 & Tarai \\
\hline 2. & Bardia NP & 1976 & 968.00 & 507.00 & Tarai \\
\hline 3. & Sagarmatha NP & 1976 & $1,148.00$ & 275.00 & Mountain \\
\hline 4. & Langtang NP & 1976 & 1710.00 & 420.00 & Mountain \\
\hline 5. & Rara NP & 1976 & 106.00 & 198.00 & Mountain \\
\hline 6. & SheyPhoksundo NP & 1984 & 3555.00 & 1349.00 & Mountain \\
\hline 7. & Khaptad NP & 1984 & 225.00 & 216.00 & Mountain \\
\hline 8. & Makalu Barun NP & 1991 & 1500.00 & 830.00 & Mountain \\
\hline 9. & ShivapuriNagarjunNP & $1989(2002 *)$ & 159.00 & 118.61 & Midhills \\
\hline 10. & Banke NP & 2010 & 550.00 & 343.00 & Tarai \\
\hline 11. & Sukhlaphanta NP & $1976(2017 *)$ & 305.00 & 243.50 & Tarai \\
\hline
\end{tabular}


Patan Pragya (Volume: 6, Number: 1 2020)

\begin{tabular}{|c|c|c|c|c|c|}
\hline 12. & Parsa NP & $1984\left(2017^{*}\right)$ & 627.39 & 285.30 & Tarai \\
\hline \multicolumn{6}{|c|}{ Wildlife Reserve } \\
\hline 13. & KoshiTappu WR & 1976 & 175.00 & 173.00 & Tarai \\
\hline \multicolumn{6}{|c|}{ Hunting Reserve } \\
\hline 14. & Dhorpatan HR & 1987 & 1325.00 & - & Mountain \\
\hline \multicolumn{6}{|c|}{ Conservation Areas } \\
\hline 15. & Annapurna CA & 1992 & 7629.00 & - & Mountain \\
\hline 16. & Manaslu CA & 1998 & $1,663.00$ & - & Mountain \\
\hline 17. & Kanchanjunga CA & 1997 & $2,035.00$ & - & Mountain \\
\hline 18. & Api Nampa CA & 2010 & $1,903.00$ & - & Mountain \\
\hline 19. & Gaurishankar CA & 2010 & $2,179.00$ & - & Mountain \\
\hline 20. & Krishnashar CA & 2009 & 16.95 & - & Tarai \\
\hline
\end{tabular}

Note: $\mathrm{NP}=$ National parks; $\mathrm{WR}=$ Wildlife reserve; $\mathrm{HR}=$ Hunting reserve: $\mathrm{CA}=$ Conservation Area;* Upgraded to National park.

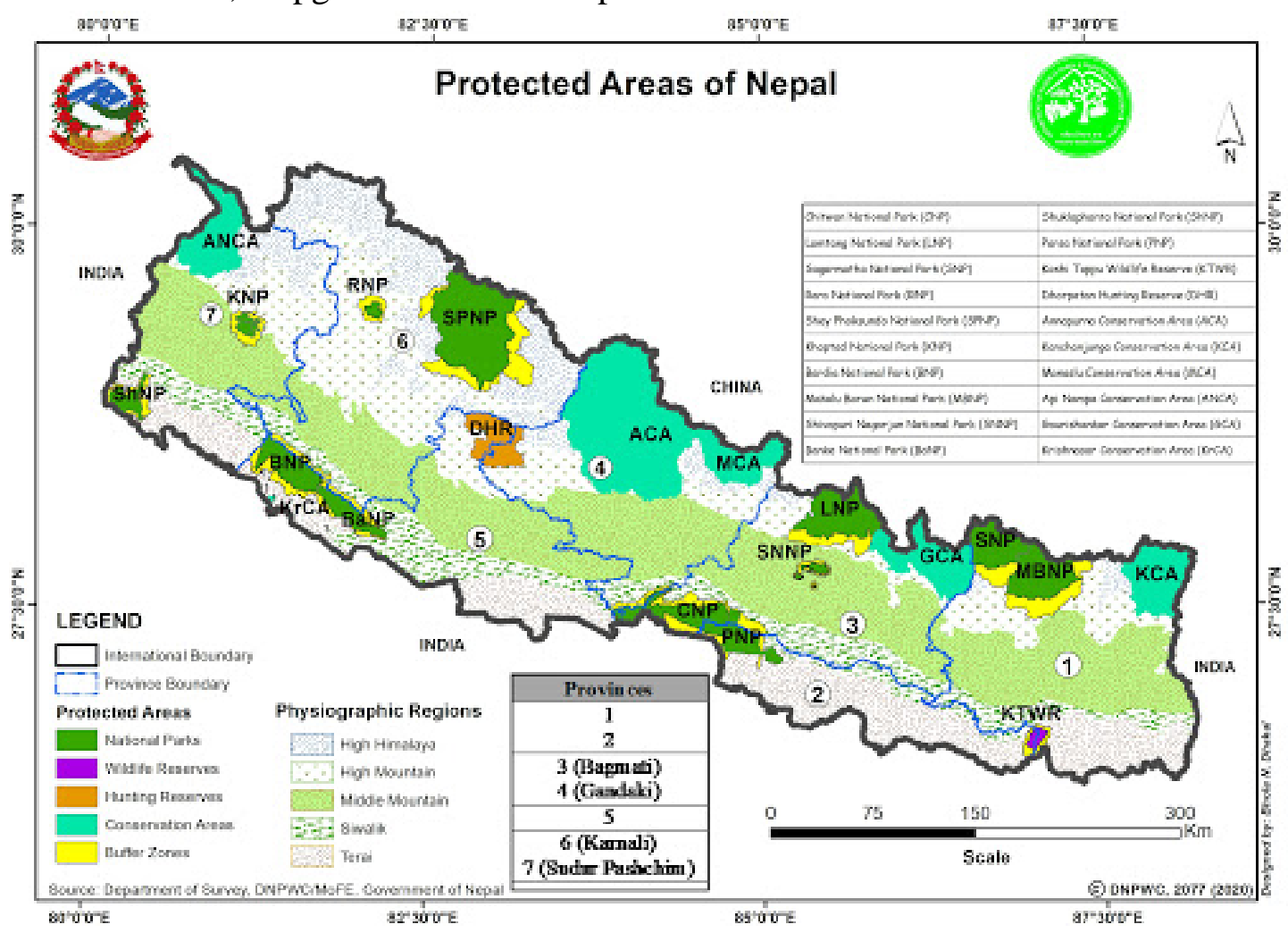

Fig.1. Protected Areas of Nepal (Source: https://www.dnpwc.gov.np)

\section{Forest management}


Besides the PAs, different types of forests such as Government managed forest, Community forest, Leasehold forest,Collaborative forest, Protection forest, Religious forest and private forest are also the means of in-situ conservation (MoFE, 2018).

Forest covered $43.5 \%$ of areas in Nepal in 1960 but drastically decrease to reach $38.1 \%$ in 1978 and 29\% in 1994 (DFRS, 2015). However, forest increased and recovered until reaching 39.1\% in 2010 (Uddin et al., 2015), 40.36\% in 2015 (DFRS, 2015) and 44.47\% in 2018 (MoFE, 2019).Satellite based study has also showed increased forest in Nepal during last three decades (Baniya et al., 2018).Most of the accessible forests are handed over and managed under different categories (community forest, collaborative forests, leased forest) for multiple uses under forest users (Poudel, 2018). Bythe community mobilization in the forest for over three decades, the forests in middle mountains and high mountains have increased in terms of area and quality (DFRS, 2015). But within the same periods, the forests in Churia foot hills, Siwaliks and Tarai continued to degrade due to serious challenges such as land encroachment, forest fire, over grazing, over exploitation (Poudel, 2018). Many rural communities still depend upon the forest products for their livelihood and primary health care wholly and partly. Moreover, the selling of different forest products and services, including timber, non-timber forest products (NTFPs) and ecotourism, has become a significant source of revenue generation for GoN (Subedi et al., 2014). However, lack of scientific forest management in the past, some forests, mostly in the accessible areas, are over matured while the others are exploited leading to forest degradation (Poudel,2018). Though the forestry sector in Nepal has economic, environmental and socio-cultural potential but conservation centered management has been losing its benefits (Jayasawal and Bishwokarma, 2016). Realizing the urgent need for sustainable management of Nepal's forest and recognizing the huge potentialfor prosperity through forestry, a new vision on forestry "Forestry for Prosperity" was announced by Government of Nepal (GoN) in 2012 (Poudel, 2018).The vision contained four major pillars of prosperity viz. sustainable and scientific management, sustainable use of forest products and services, commercialization and marketing of forest resources and creating enabling environment (Poudel, 2018). The vision thus laid the foundation for scientific forest management (SciFM) and for sustainable management in Production forests.Later on, governmentalso developed and enacted the Scientific Management Guidelines in 2014. The government has defined the SciFM as "an application of appropriate silviculture system and forest management principles through design of systematic compartment of fixed rotation age" (Poudyal et al., 2019). The Sustainable forest management was aimed to maintain and enhance the economic, social and environmental values of all types of forests, for the benefit of present and future generations (FAO, 2020). The terms "Scientific forest management" and "sustainable forest management" have been used and understood interchangeably in the global forestry 
scenario in recent decades linking management activities to principles of sustainable development (Jayasawal and Bishwokarma 2016). The vision encouraged the promotion of sustainable forest management initiatives especially in the high value timber species and in 2012 and later with support from Multi Stakeholder Forestry Programme (MSFP) in 2013, the Department of Forests (DoF) repiloted SciFM in the high value Sal (Shorea robusta) forest in Tilauakot collaborative forest in Kapilvastu, employing advanced silvicultural systems (Jayasawal and Bishwokarma 2016). Later on SciFM has been also been started in at least one forest in eight district including Morang, Makawanpur,Chitwan, Nawalparasi, Kapilbastu,Rupendehi, Palpa and Kailali using intensive silvicultural operations in 26,000 ha of forests (Jayasawal and Bishwokarma 2016). As of March 2018, 81,500 ha of the production forest are under SciFM programme (MoFE, 2018).

4.2. Ex-situ ConservationThough conserving the biodiversity in natural habitat is the ideal method, but biodiversity should also be conserved as ex-situ. Conservation of the components of biodiversity outside their natural habitats is referred as ex-situor off-site conservation. Habitat loss, extinction of species, human population growth, intervention on the natural habitat etc. recalls the need for ex-situ conservation of biodiversity.Rare, endangered, threatened and endemic species are especially needed to be conserved in $e x-$ situ. Article 9 of CBD promotes each contracting parties to adopt measures for ex-situ conservation of components of biological diversity, preferably in the country of origin of such components, for the purpose of complementing in-situ conservation. In 2010, CBD adopted the updated Global Strategy for Plant Conservation (GSPC) 2011-2020 with 16 targets for plant conservation to be achieved by 2020 (https://www.cbd.int/gspc/targets.shtml). According to target 8 of GSPC, at least $75 \%$ of threatened plant species in ex-situ, preferably in the country of origin, and at least $20 \%$ available for recovery and restoration programs is urgently and effectively conserved (https://www.cbd.int/gspc/targets.shtml).Ex-situ conservation strategies play the important role in conservation of plants species vulnerable to the climate change. The different methods of ex-situ conservation are the botanical gardens, seed gene bank, in vitro storage, cryopreservation etc.

\section{Botanical Gardens}

Botanical gardens are the main important ex-situ conservation sites and help in conservation and management of plant diversity. Botanical gardens play the crucial role in the conservation of plant diversity especially the rare, endangered, threatened and endemic plant species. Department of Plant Resources (DPR), Government of Nepal (GoN), has established 12 Botanical gardens covering an area of 745.92 ha in nine districts(Lamichhane, 2018) (Table3.).Moreover, GoN has envisioned establishing botanical garden in each of 7 states of Nepal (MoFE, 2018) 
Patan Pragya (Volume: 6, Number: 1 2020)

Table 3.Botanical Gardens of Nepal.

\begin{tabular}{|l|l|l|l|l|l|}
\hline SN & $\begin{array}{l}\text { Botanical Garden } \\
\text { (BG) }\end{array}$ & Locality/District & Area (ha.) & Altitude (m) & $\begin{array}{l}\text { Vegetation } \\
\text { Zone }\end{array}$ \\
\hline 1. & National BG & $\begin{array}{l}\text { Godavari, } \\
\text { Lalitpur }\end{array}$ & 82 & 1515 & Sub-tropical \\
\hline 2. & Mai Pokhari BG & $\begin{array}{l}\text { Mai } \\
\text { pokhari/Ilam }\end{array}$ & 9 & 2200 & Temperate \\
\hline 3. & Dhanusadham BG & $\begin{array}{l}\text { Dhanushadham/ } \\
\text { Dhanusa }\end{array}$ & 20.27 & 100 & Tropical \\
\hline 4. & Vrindaban BG & $\begin{array}{l}\text { Padampokhari/ } \\
\text { Makawanpur }\end{array}$ & 96 & 500 & Tropical \\
\hline 5. & Mountain BG & $\begin{array}{l}\text { Daman/Makawa } \\
\text { npur }\end{array}$ & 65 & 2320 & Temperate \\
\hline 6. & Tistung BG & $\begin{array}{l}\text { Tistung/Makawa } \\
\text { npur }\end{array}$ & 45 & 1700 & Sub-tropical \\
\hline 7. & $\begin{array}{l}\text { World } \\
\text { Biodiversity Garden }\end{array}$ & $\begin{array}{l}\text { Raniban, } \\
\text { Pokhara/ Kaski }\end{array}$ & 164 & 775 & Sub-tropical \\
\hline 8. & Mukeri BG & Banke & 5 & 130 & Tropical \\
\hline 10. & Dhitachaur BG & $\begin{array}{l}\text { Kapurkot/Salyan } \\
\text { a }\end{array}$ & 5.65 & 2000 & Temperate \\
\hline 11. & Deoria BG & Deoria/Kailali & 149.5 & 170 & Temperate \\
\hline 12. & Godavari BG & $\begin{array}{l}\text { Godavari, } \\
\text { Kailali }\end{array}$ & 100 & 185 & Tropical \\
\hline
\end{tabular}

\subsubsection{Protected plant species in Nepal}

GoN under the Forest Act 1993 has protected some plant species under different categoriesto avoid the decline in their population in natural habitats (Table 4.).

Table4. List of plant species legally protected in Nepal.

\begin{tabular}{|c|c|c|}
\hline Scientific Name & Common/English Name & Local name \\
\hline \multicolumn{3}{|c|}{ A. Plant species banned for collection, use, sale, distribution, transportation and export } \\
\hline \multicolumn{3}{|l|}{ Angiosperms } \\
\hline Juglansregia & Walnut & Okhar \\
\hline Dactylorhizahatagirea & - & Panchaunle \\
\hline Neopycrorhizascrophulariiflora & Gentian & Kutki \\
\hline
\end{tabular}


Patan Pragya (Volume: 6, Number: 1 2020)

B. Plant species banned for export except for processed with permission of Department of Forests

Angiosperms

\begin{tabular}{|l|l|l|}
\hline Cinnamomumglaucescens & - & Sugandhakokila \\
\hline Cordycepssinensis & - & Yarsagumba \\
\hline Rauvolfia serpentine & Sepentine & Sarpagandha \\
\hline Valerianajatamansi & Spikenard & Jatamansi \\
\hline Valerianawallichii & Valerian & Sugandhawal \\
\hline Gymnosperm & & \\
\hline
\end{tabular}

Gymnosperms

\begin{tabular}{|l|l|l|}
\hline Abiesspectabilis & Fir & Talispatra \\
\hline Taxusbaccata & Himalayan yew & Loth salla \\
\hline Taxuswallichiana & East Himalayan Yew & \\
\hline Taxuscontorta & West Himalayan Yew & \\
\hline
\end{tabular}

Lichens

\begin{tabular}{|l|l|l|} 
Parmelia spp. & Lichen & Jhayu \\
\hline
\end{tabular}

C. Plant species banned for harvest, transportation and export for commercial purposes

\begin{tabular}{|c|c|c|}
\hline Angiosperms & & \\
\hline Acacia catechu & Cutch Tree & Khayar \\
\hline Bombaxmalabaricum & Silk cotton tree & Simal \\
\hline Dalbergialatifolia & Rose wood & Satisal \\
\hline Micheliachampaca & Magnolia & Champ \\
\hline Pterocarpusmarsupium & Indian Kino tree & Bijaya Sal \\
\hline Shorearobusta & Common sal & Sal \\
\hline
\end{tabular}

Source: GoN/MoFSC (2014b) 


\subsubsection{CITES listed Plant species of Nepal}

Convention on International Trade in Endangered species of Wild Fauna and Flora (CITES) is a multilateral treaty for the protection of endangered animal and plant species.The increasing demand of the wild life in the world has created the illegal collection and trade of the wild lifeleading to the erosion of many species,making them vulnerable to extinction. To control the threatened wild species, the agreement was made between the governments of world to ensure that international trade in specimens of wild animals and plants does not threaten their survival. CITES was drafted as a result of resolution in1963 at a meeting of members of IUCN (The World Conservation Union). Nepal being a signatory party in CITES since 1975, has enlisted a number of plant species from Nepal under various CITES appendices (Table 5.).

Table 5. List of Plant species under CITES appendices.

\begin{tabular}{|c|c|c|c|}
\hline Appendix & Scientific name & Family & $\begin{array}{l}\text { Nepali } \\
\text { name/Local } \\
\text { Name } \\
\end{array}$ \\
\hline \multirow{2}{*}{$\begin{array}{c}\text { Appendix I } \\
\text { (Restricted for } \\
\text { trade worldwide) }\end{array}$} & $\begin{array}{l}\text { Paphiopediluminsinge(Wall. ex } \\
\text { Lindl.) Pfitzer }\end{array}$ & Orchidaceae & \\
\hline & $\begin{array}{l}\text { Paphiopedilumvenustum(Wall. ex } \\
\text { Sims.) Pifitz. }\end{array}$ & Orchidaceae & \\
\hline \multirow{7}{*}{$\begin{array}{l}\text { Appendix II } \\
\text { (Regulated trade; } \\
\text { export permit } \\
\text { required) }\end{array}$} & $\begin{array}{l}\text { Rauvolfia serpentine (L.) Benth. ex } \\
\text { Kurz }\end{array}$ & Apocynaceae & $\begin{array}{l}\text { Sarpangandha/ } \\
\text { chandmaruwa }\end{array}$ \\
\hline & PodophyllumhexandrumRoyle & Berberidaceae & $\begin{array}{l}\text { Laghupatra/Papr } \\
\text { a/ Ban Bhata }\end{array}$ \\
\hline & $\begin{array}{l}\text { Dalbergiaspp. } \\
\text { DalbergialatifoliaRoxb. } \\
\text { Dalbergiapinnata(Lour.) Prain } \\
\text { DalbergiasericeaG.DonDalbergiasis } \\
\text { sooRoxb. ex DC. } \\
\text { DalbergiastipulaceaRoxb. } \\
\text { DalbergiavolubilisRoxb. } \\
\end{array}$ & Leguminosae & $\begin{array}{l}\text { Satisal } \\
\text { Daamar } \\
\text { Sisau }\end{array}$ \\
\hline & $\begin{array}{l}\text { Cyatheaspp. } \\
\text { Cyatheabrunoniana(C.B.Clarke) } \\
\text { C.B. Clarke \& Baker } \\
\text { Cyathea gigantean (Wall. ex Hook.) } \\
\text { Holttum } \\
\text { Cyatheakhasyana (Moore ex Kuhn) } \\
\text { Domin } \\
\text { Cyatheaspinulosa Wall. ex Hook.. }\end{array}$ & Cyatheaceae & Rukhuneu \\
\hline & CycaspectinataBuch.-Ham. & Сycadaceae & Kalbal/Thakal \\
\hline & Dioscoreadiltoidea Wall. exGriseb. & Dioscoreaceae & Kukurtarul \\
\hline & Euphorbia spp. & Euphorbiaceae & \\
\hline
\end{tabular}




\begin{tabular}{|c|c|c|c|}
\hline & $\begin{array}{l}\text { Euphorbia fusiformisBuch.-Ham. ex } \\
\text { D.Don } \\
\text { Euphorbia prostrata Aiton } \\
\text { Euphorbia royleanaBoiss }\end{array}$ & & $\begin{array}{l}\text { KanikeGhans } \\
\text { Siundee }\end{array}$ \\
\hline & Orchidaceae spp. & Orchids & \\
\hline & TaxuswallichianaZucc. & $\begin{array}{l}\text { Himalayan } \\
\text { yew }\end{array}$ & $\begin{array}{l}\text { Lauthsalla, } \\
\text { talispatra }\end{array}$ \\
\hline & Taxuscontorta & & \\
\hline & NardostachysgrandifloraDC. & & \\
\hline \multirow{4}{*}{$\begin{array}{l}\text { Appendix III } \\
\text { (Regulated trade } \\
\text { from Nepal) }\end{array}$} & Meconopsisregia & $\begin{array}{l}\text { Himalayan } \\
\text { yellow poppy }\end{array}$ & Kyashar \\
\hline & Gnetummontanum & Gnetum & Bhotelahara \\
\hline & Podocarpusneriifolius & Podocarpus & Gunsi \\
\hline & Tetracentronsinensis & Tetracentron & Jharikot \\
\hline
\end{tabular}

Source: Joshi et al., 2017

\subsubsection{Prioritized plant species in Nepal}

Natural resources of Nepal are the prized procession of the country, the proper utilization of which can enhance the economy of nation. Biodiversity is closely linked to livelihood of Nepalese people. Being the plant diversity rich country, one of the sectors in which the country has relative advantage is the medicinal and aromatic plants. Hence the GoN has prioritized 33 medicinal plants (MPs) for research andeconomic development of nation (DPR, 2006; 2016) (Table 6.).

Table 5. List of MPs prioritized by GoN.

\begin{tabular}{|c|c|c|c|}
\hline SN & Scientific Name & Family & Nepali Name \\
\hline 1. & Aconitum heterophyllumWall. ex Royle & Ranunculaceae & Atish \\
\hline 2. & $\begin{array}{l}\text { Aconitum lethaleGriff. } \\
\text { Synonym: Aconitum spicatum (Bruhl) Stapf } \\
\text { Aconitum ferox var. spicatumBruhl }\end{array}$ & Ranunculaceae & Bikha \\
\hline 3. & Acoruscalamus Linn. & Acoraceae & Bojho \\
\hline 4. & Asparagus racemosusWilld. & Asparagaceae & Satawari \\
\hline 5. & AzadirachtaindicaA.Juss. & Meliaceae & Neem \\
\hline 6. & Bergeniaciliata (Haw.) Sternb. & Saxifragraceae & Pakhanbhet \\
\hline 7. & $\begin{array}{l}\text { Cinnamomumglaucescens (Nees) Hand.- } \\
\text { Mazz. }\end{array}$ & Lauraceae & $\begin{array}{l}\text { Sugandhakokil } \\
\text { a }\end{array}$ \\
\hline 8. & $\begin{array}{l}\text { Cinnamomumtamala } \quad \text { (Buch.-Ham.) } \\
\text { T.Nees\&Eberm }\end{array}$ & Lauraceae & Tejpat \\
\hline 9. & CurculigoorchioidesGaertn. & Hypoxidaceae & KaloMusali \\
\hline 10. & Dactylorhizahatagirea(D. Don.) Soo & Orchidaceae & Panchaaule \\
\hline
\end{tabular}


Patan Pragya (Volume: 6, Number: 1 2020)

\begin{tabular}{|c|c|c|c|}
\hline 11. & Dioscoreadeltoidea Wall. exGriseb. & Dioscoreaceae & Bhyakur \\
\hline 12. & FritillariacirrhosaD. Don. & Liliaceae & Kakoli \\
\hline 13. & Gaultheria fragrantissima Wall. & Ericaceae & Dhasingare \\
\hline 14. & Juglansregia Linn. & Juglandaceae & Ookhar \\
\hline 15. & Lichens spp & - & Jhyau \\
\hline 16. & Morchellaspp. & Pezizaceae & $\begin{array}{l}\text { KhoyaChyau/ } \\
\text { GuchchiChyau }\end{array}$ \\
\hline 17. & $\begin{array}{l}\text { Nardostachysjatamansi (D.Don.) DC. } \\
\text { Synonym: Nardostachysgrandiflora DC. }\end{array}$ & Caprifoliaceae & Jatamansi \\
\hline 18. & $\begin{array}{l}\text { Neopicrorhizascrophulariiflora (Pennell) } \\
\text { D.Y.Hong } \\
\text { Synonym: Picrorhizascrophulariiflora Pennell }\end{array}$ & Plantaginaceae & Kukti \\
\hline 19. & $\begin{array}{l}\text { Ophiocordycepssinensis (Berk.) G.H. Sung } \\
\text { \&J.M.Sung, Hywel-Jones \&Spatafora } \\
\text { Synonym:Cordycepssinensis (Berk.) Sacc., } \\
\text { Fungi,) }\end{array}$ & Clavicipitaceae & Yarsagumba \\
\hline 20. & Paris polyphyllaSm. & Melanthiaceae & Satuwa \\
\hline 21. & Phyllanthusemblica Linn. & Phyllanthaceae & Amala \\
\hline 22. & Piper longum Linn. & Piperaceae & Pipala \\
\hline 23. & Rauvolfiaserpentina (L.) Benth. ex Kurz & Apocynaceae & Sarpagandha \\
\hline 24. & $\begin{array}{l}\text { Rheum australeD.Don. } \\
\text { Synonym: Rheum emodiiWall. exMeisn. }\end{array}$ & Polygonaceae & Padamchal \\
\hline 25. & RubiamanjithRoxb. ex Fleming & Rubiaceae & Majitho \\
\hline 26. & SapindusmukorossiGaertn. & Sapindaceae & Riththa \\
\hline 27. & $\begin{array}{l}\text { Sinopodophyllumhexandrum(Royle) } \\
\text { Ying } \\
\text { Synonyms:PodophyllumhexandrumRoyle } \\
\text { Podophyllumemodi Wall. ex Hoof. f. \& } \\
\text { Thomos }\end{array}$ & Berberidaceae & Laghupatra \\
\hline 28. & $\begin{array}{l}\text { Swertiachirayita (Roxb.ex Fleming) Karsten } \\
\text { Synonym: Swertiachirata(Wall.) C.B.Clarke } \\
\text { GentianachirayitaRoxb. ex Fleming }\end{array}$ & Gentianaceae & Chiraito \\
\hline 29. & TagetesminutaLinn. & Asteraceae & $\begin{array}{l}\text { JangaliSayapat } \\
\text { ri }\end{array}$ \\
\hline 30. & TaxuswallichianaZucc. & Taxaceae & LauthaSalla \\
\hline
\end{tabular}




\begin{tabular}{|l|l|l|l|}
\hline & $\begin{array}{l}\text { Synonym: Taxusbaccatasubsp. wallichiana } \\
\text { (Zucc.) Pilg. }\end{array}$ & \\
\hline 31. & Tinosporasinensis (Lour.) Merr. & Menispermaceae & Gurjo \\
\hline 32. & ValerianajatamansiiJones & Caprifoliaceae & Sugandhawal \\
\hline 33. & Zanthoxylumarmatum DC. & Rutaceae & Timur \\
\hline
\end{tabular}

Source: DPR 2006, 2016.

Among 33 prioritized MPs, 13 plant species viz. Curculigoorchioide, Dactylorhizahatagirea, Fritillariacirrhosa, Morchellaspp., Nardostachysjatamansi, Neopicrorhizascrophulariiflora,Ophiocordycepssinensis, Paris polyphylla, Piper longum, Rauvolfia serpentine, Swertiachirayita, Taxuswallichiana, Tinosporasinensis, are prioritized for the agro-technology development (DPR, 2006; 2016).

\section{Conclusion}

Plant diversity in Nepal is closely linked to livelihood and economic well beings of Nepalese people. People in rural areas still depend upon the plant diversity around them for their livelihood. Biodiversity should be conserved and used in a sustainable way to safeguard the aspirations of present and future generations. Every plant species in the earth matters whether it is small or large and needs to be protected. In-situ and ex-situ conservation practices in fact play the major role in conservation of plant diversity and are practiced in Nepal. The PAs besides conservation of nature and natural resources are also the attraction spots for the tourists and thus help to enhance the economy of nation. The habitats with rare, endangered, endemic, taxonomically important and with high number of species needto be established as PAs. ThePAs must be actively managed and monitored regularly to prevent the deterioration.The well designed management plan is crucial to prevent the biodiversity loss inPAs. Though establishing the PAs is essential for biodiversity conservation but it is short-sighted to depend totally on PAs for biodiversity conservation and protection of species need be done outside the PAs as well. Forests are the main habitat where the rich plant diversity is found. The indigenous people use to apply their wisdom and management practices to save and promote the biodiversity for their survival for the long time. Hence the local knowledge and practices needs to be considered for the conservation outside the PAs.Besides the in-situconservation, ex-situ conservation of threatened and endangered plant species help in recovery, rehabilitation and their introduction in natural habitat. Ex-situ conservation needs to be carried out in different bioclimatic zones of the country and botanical gardens needs to establish in each zone.

In-situ and ex-situ conservation practices besides the conservation of biodiversity and ecosystem, also help in ecotourism development and hence enhance the economy of nation. Moreover, biodiversity can be well conserved if the people become aware about the 
consequences of the loss of biodiversity which can be achieve by various methods such as education, communication, outreach programs.

\section{References}

Allen, J.C. and Barnes, D.F. (1985). The causes of deforestation in developing countries. Ann. Assoc. Am. Geogr. 75 (2): 163-184.

Baniya, B., Tang Q., Huang, Z., Sun, S. and Techato, K-A. (2018). Spatial and Temporal Variation of NDVI in Response to Climate Change and the implication for Carbon Dynamics in Nepal. Forest 9:329.

Doi: https//doi.org/10.3390/f9060329

Barthlott, W., Mutke, J., Rafiqpoor, D., Kier, G. and Kreft, H. (2005).Global Centers of Vascular Plant Diversity.NovaActaLeopoldina NF 92, Nr. 342.Pp: 61-83.

Basnet, K. (1992). Conservation Practices in Nepal: Past and Pesent. Ambio 21 (6): 390-393.

CBD, (1992).Convention of Biological Diversity, United Nations.

CBD, (2010).The Convention on Biological Diversity, Year in Review 2010. Secretariat of the Convention on Biological Diversity, United Nations Environment Programme, Canada.

Chaudhary, R.P., Uprety, Y. and Rimal, S.K. (2015). Deforestation in Nepal: Causes, Consequences, and Responses. In: Shroder JF, Sivanpillai R (eds.). Biological and Environmental Hazards, Risks and Disasters, Hazards and Disaters series. Chapter 12.2. :335-372 Elesevier.

Dasman, R.F. (1968). A Different Kind of Country. Macmillan, New York, USA.DFRS, (2015).State of Nepal's Forests.Forest Resource Assesssment (FRA) Nepal, Department of Forest Research and Survey, Kathmandu, Nepal.

De Vos, J.M., Joppa, L.N., Gittleman, J.L., Stephens, P.R. and Pimm, S.L. (2014).Estimating the Normal Background Rate of Species Extinction.Conservation Biology.29(2).Pp. 452-462.

DFRS, (2015). State of Nepal's Forests. Forest Resource Assesssment (FRA) Nepal, Department of Forest Research and Survey, Kathmandu, Nepal.

DNPWC, (2075 B.S). Shrestha BP and Panth BR (eds.). Protected Areas of Nepal (In Nepali).Department of National Parks and Wildlife Conservation, Babarmahal, Kathmandu, Nepal.

DPR, (2016).News letter (BanaspatiShrota).Department of Plant Resources, Ministry of Forest and Soil Conservation, Thapathali, Kathmandu, Nepal.19 (4).

DPR, (2006).Plants of Nepal: Fact Sheet. Department of Plant Resources, Ministry of Forest and Soil Conservation, Thapathali, Kathmandu, Nepal.

FAO (2020). Food and Agriculture Organisation of the United Nations (FAO). Sustainable Forest Management. 
Patan Pragya (Volume: 6, Number: 1 2020)

http://www.fao.org/forestry/sfm/en/ . Accessed on 3 November, 2020

Glowka, L., Burhenne-Guilmin, F., And Synge, H., McNeely J.A. and Gundling, L. (1994). A Guide to the Convention on Biological Diversity.IUCN, Gland and Cambridge.P. 39.

DOI: 10.1111/cobi.12380

Groombridge, B. and Jenkins, M.B. (2000).Global Biodivesity: Earth's Living Resources in the $21^{\text {st }}$ Century. World Conservation Press, Cambridge, UK

Jayasawal, D. and Bishwokarma, D. (2016). Scientific Forest Management Initiatives in Nepal: MSFP Experiences and Lessons Learnt. Multi-Stakeholder Forestry Programme, Nepal. A Programme of the Government of Nepal (GoN) supported by the Government of Finland, Switzerland and United Kingdom.

Doi: 10.13140/RG.2.2.15707.92960

Joshi, N., Sharma (Dhakal), K. and Saud, D.S. (2017).Checklist of CITES Listed Flora of Nepal. Government of Nepal, Ministry of Forest and Soil Conservation, Department of Plant Resources, Thapathali, Kathamndu, Nepal.

Kharal, D.K. and Dhungana, M. (2018). Forest Coverage and Biodiversity in Nepal. In: Dhakal, M., Lamichhane, D., Ghimire, M.D., Poudyal, A., Uprety, Y., Svich, T. and Pandey, M. (eds.). 25 Years of Achievements on Biodiversity Conservation in Nepal.Ministry of Forests and Environment, Government of Nepal.Singha Durbar, Kathmandu, Nepal. Pp. 23-25.

Lamichhane, D. (2018). Ex-situ Conservation of Plants and Botanical Gardens in Nepal. In: Dhakal M., Lamichhane D., Ghimire MD., Poudyal A., Uprety Y., Svich T. and Pande M. (eds.). 2018. 25 Years of Achievements on Biodiversity Conservation in Nepal. Ministry of Forests and Environment, Government of Nepal.Singha Durbar, Kathmandu, Nepal. Pp. 61-65.

MoFE (2019). National level Forests and Land Cover Analysis of Nepal using Google Earth images. Ministry of Forests and Environment, Forest research and Training Centre, Kathmandu.

MoFE, (2018). Nepal's Sixth National Report to the Convention on Biological Diversity. Government of Nepal.Ministry of Forests and Soil Conservation (MoFE), Singh Durbar, Kathamndu, Nepal.

MoFSC, (2014a).Nepal Fifth National Report to Convention on Biological Diversiy.Ministry of Forests and Soil Conservation, Government of Nepal.Kathmandu. P.9

MoFSC, (2014b).Nepal National Biodiversity Strategy and Action Plan:2014-2020.Ministry of Forests and Soil Conservation, Government of Nepal. Kathmandu.P. 17, 177.

MoFSC, (2002).Nepal Biodiversity Strategy 2002.Ministry of Forests and Soil Conservation, His Majesty’s Government of Nepal, Kathmandu, Nepal. 
Poudel, K.C. (2018). Silviculture for forest management in Nepal. Banako Jankari 27 (3): $15-20$.

Doi: http//doi.org/10.3126/banko.v27i3.20537

Poudyal, B.H., Marseni, T. and Cockfield, G. (2019). Scientific Forest Management Practice In Nepal: Critical Reflections from Stakeholders’ Perspectives. Forests 11 (1): 120Doi: 10.3390/f11010027

Shrestha, K.K. (2016). Global Biodiversity and Taxonomic Initiatives in Nepal. In: Jha, P.K., Siwakoti, M., and Rajbhandary, S. (eds.). Frontiers of Botany.Central Department of Botany (CDB), Kirtipur, Kathmandu, Nepal.Pp: 177-223.

Shrestha,P.M. and Dhillion, S.S. (2003). Medicinal plant diversity and use in the highlands of Dolkha district, Nepal. Journal of Ethnopharmacology 86 (1): 81-96.

Subedi, B.P., Ghimire, P.L., Koontz, A.,Khanal, S.C., Katwal, P., Sthapit, K.L. and Mishra, S.K. (2014). Private Sector Involvement and Investment in Nepal's Forestry: Status, Prospects and Ways Forward Study Report. Multi-Stakeholder Forestry ProgrammeService Support Unit. Babarmahal, Kathmandu.

Uddin K., Shrestha, H.L., Murthy, M.S.R., Bajracharya, B., Shrestha, B., Gilani, H., Pradhan, S. and Dangol, B. (2015). Development of 2010 national land cover database for the Nepal. Journal of Environmental Management 148:82-90.

Doi: 10.1016/j.jenvman.2014.07.047MoFE (2019).

Websites

www.iucnredlist.org, 2020.

https://www.cbd.int/gspc/targets.shtml 